\title{
Nudaciraxine imperium sp.n. (Monogenea: Axinidae) from the gills of Mediterranean needlefish Tylosurus acus imperialis (Teleostei: Belonidae)
}

\author{
Manel Châari, Hela Derbel and Lassâd Neifar
}

Laboratoire de Biodiversité et Ecosystèmes Aquatiques, Département des Sciences de la Vie, Faculté des Sciences de Sfax, BP 1171, 3000 Sfax, Tunisia

\begin{abstract}
Nudaciraxine imperium sp. n. (Monogenea: Axinidae) is described from the gills of the needlefish Tylosurus acus imperialis (Rafinesque) caught in the Gulf of Gabès, Tunisia. This new species mainly differs from both previously described species, Nudaciraxine gracilis (Linton, 1940) Price, 1962 from Strongylura marina (Walbaum) and Nudaciraxine cabosanlucensis Payne, 1990 from Ablennes sp., by having more testes (42 vs. 20-22 and 32, respectively). Nudaciraxine imperium also differs from N. gracilis by having a median vaginal pore (submedian in $N$. gracilis), narrower clamps (52-70 $\mu \mathrm{m}$ vs. $75-100 \mu \mathrm{m})$ and differently shaped haptoral lateral hamuli. From N. cabosanlucensis it can be distinguished by a J-shaped rather than U-shaped ovary, a longer cirrus pouch $(125-190 \mu \mathrm{m}$ vs. 64-70 $\mu \mathrm{m}$ ), an oesophageal bifurcation slightly anterior to genital complex (immediately after pharynx in N. cabosanlucensis) and a wider guard on the lateral hamuli. In agreement with Payne (1990), the diagnosis of the genus Nudaciraxine Price, 1962 is amended as follows: vaginal pore dorsal, median to submedian, armed or not with horn-like spines. This is the first report of the genus Nudaciraxine in the Mediterranean Sea. The potential use of axinid monogeneans as biological tags for subspecies of belonid fishes is discussed.
\end{abstract}

Keywords: Monogenea, Axinidae, Nudaciraxine imperium, gill parasite, Tylosurus acus imperialis, Belonidae, Tunisia, Mediterranean Sea

The needlefish Tylosurus acus (Lacépède) is an epipelagic teleost marine fish, widely distributed in the tropical and subtropical zones of the world. Four subspecies are recognised according to their geographical distribution (Collette 2003): Tylosurus acus acus (Lacépède) in the Western Atlantic, Tylosurus acus rafale Collette et Parin in the Gulf of Guinea, Tylosurus acus imperialis (Rafinesque) in the Mediterranean Sea, and Tylosurus acus melanotus (Bleeker) throughout the Indo-Western Pacific, extending to the Eastern Pacific.

Tylosurus acus has been reported as a host of monogeneans belonging to the Axinidae Unnithan, 1957 in different localities. Axine belones Abildgaard, 1794 has been reported in the Mediterranean Sea (Palombi 1949), Nudaciraxine gracilis (Linton, 1940) Price, 1962 in the Gulf of Mexico (Bravo-Hollis 1984), Axine resplendens Cabellero, Bravo-Hollis et Grocott, 1954 and Axinoides raphidoma Hargis, 1956 in the Eastern Pacific (Pérez-Ponce de León et al. 1999), Neoaxine constricta (Yamaguti, 1938) Price, 1946 in the South China Sea (Zhang et al. 2003) and Chlamydaxine sp. and Nudaciraxine sp. in the Western Atlantic (Tavares et al. 2004).

During a recent parasitological study on fishes in the Gulf of Gabès (Tunisia), three species of Monogenea were collected from T. a. imperialis: Aspinatrium gallieni Euzet et Ktari, 1971 (Microcotylidae) on the inner side of the operculum and also two additional previously undescribed axinid species on the gills. In this paper we describe one of these, the most abundant axinid monogenean, as a new species of Nudaciraxine. The potential use of axinid monogenean as biological tags for subspecies of belonid fishes Tylosurus is discussed.

\section{MATERIALS AND METHODS}

Between May and July of 2004, 2006 and 2007, 74 specimens of T. a. imperialis caught in the Gulf of Gabès (Tunisia) by local fishermen using gill nets were examined. This fish inhabits offshore waters, but can be found in coastal waters during spring and summer. Specimens were identified using Bauchot (1987).

Fish were dissected and examined a few hours after capture. The operculum and gill arches were separated and placed in Petri dishes with filtered seawater using filter paper. Monogeneans were detected using a stereomicroscope, detached from the gills and operculum and then transferred to a dish containing filtered seawater. They were studied either alive or fixed between slide and coverslip in $70 \%$ alcohol. Fixed specimens were stained with Semichon's acetic carmine. Other specimens were double-stained with light green and Semichon's acetic carmine to study the morphology of the clamps. After dehydration 
through a graded ethanol series, specimens were cleared with clove oil and mounted in Canada balsam. Some fixed specimens were mounted in Berlese's fluid in order to study the haptoral sclerites and the genital armature.

Illustrations and measurements were made of stained specimens with the aid of a Leitz light microscope equipped with a drawing tube. Illustrations were scanned and redrawn on a computer using CorelDRAW software. All measurements are given in micrometres (unless stated otherwise) as the mean \pm standard deviation, with the range and the number of measurements (n) in parentheses.

\section{RESULTS}

Axinidae Unnithan, 1957

Nudaciraxine imperium sp. $\mathrm{n}$.

Figs. 1-3

Description (based on 30 adult specimens): Body flattened dorsoventrally; $3.8 \pm 0.3 \mathrm{~mm}(2.5-5.1 \mathrm{~mm} ; \mathrm{n}=25)$ long by $500 \pm 37(300-700 ; \mathrm{n}=28)$ wide at level of ovary. Haptor asymmetrical, triangular, $1.3 \pm 0.1 \mathrm{~mm}(0.7-1.9$ $\mathrm{mm} ; \mathrm{n}=28)$ in width, elongated with straight posterior base bordered by single row of $52 \pm 2(42-58 ; n=25)$ clamps (Fig. 1). Seventy percent of specimens with haptor directed to right, line of clamps located on same side as dextral genito-intestinal canal; $30 \%$ of specimens with haptor directed to left, line of clamps facing the opposite genito-intestinal canal. Clamps $55 \pm 1 \quad(50-60 ; \mathrm{n}=15)$ long by $61 \pm 3(52-70 ; \mathrm{n}=15)$ wide. Clamp of "Axinetype" with marginal sclerites of anterior and posterior jaw, in two parts (Fig. 2C, D). Two pairs of hamuli and one pair of uncinuli situated $570 \pm 60(370-740 ; n=13)$ from posterior end of haptor. Number of clamps at right side of hamuli and uncinuli $20 \pm 1(17-22 ; \mathrm{n}=17)$; at left side $34 \pm 2(22-41 ; \mathrm{n}=19)$. Median hamuli falciform $47 \pm 1$ $(45-50 ; \mathrm{n}=10)$ long; blade, Y: $10 \pm 1(10-12 ; \mathrm{n}=11)$ articulated with long straight handle, $\mathrm{X}$ : $38 \pm 1$ (32-40; $\mathrm{n}=11)$. Lateral hamuli $34 \pm 1(28-38 ; \mathrm{n}=21)$ long with wide guard, bent shaft and short pointed blade, Y: $21 \pm 1$ $(18-23 ; n=14)$, handle, $X: 16 \pm 1(12-19 ; n=21)$. Postero-lateral uncinuli $10 \pm 1(8-10 ; n=10)$ long, between median and lateral hamuli (Fig. 2B). Anterior end bilobed, two muscular buccal suckers subcircular, aseptate, (Fig. $2 \mathrm{~A}) ; 53 \pm 3(43-70 ; \mathrm{n}=21)$ long by $38 \pm 3(25-50$; $\mathrm{n}=21$ ) wide. Mouth subterminal ventral, pharynx oval, $35 \pm 3(28-50 ; \mathrm{n}=14)$ long by $30 \pm 4(22-45 ; \mathrm{n}=12)$ wide. Oesophagus long, $400 \pm 100(300-500 ; n=4)$ from apical margin of body, caeca dendritic diverticulate laterally and medially, not extending into haptor.

Testes intercaecal, arranged in two longitudinal rows in median field with smallest at posterior extremity, $42 \pm 2$ $(37-48 ; \mathrm{n}=15)$ in number, $87 \pm 5(60-120 ; \mathrm{n}=26)$ long by $95 \pm 6(55-120 ; n=26)$ wide. Genital atrium unarmed, slightly posterior to intestinal bifurcation. Cirrus unarmed with evaginable anterior globular part. Cirrus pouch with folded muscular wall $170 \pm 9(125-190 ; n=20)$ long by $64 \pm 5(50-83 ; n=15)$ in maximum width, $43 \pm 3$

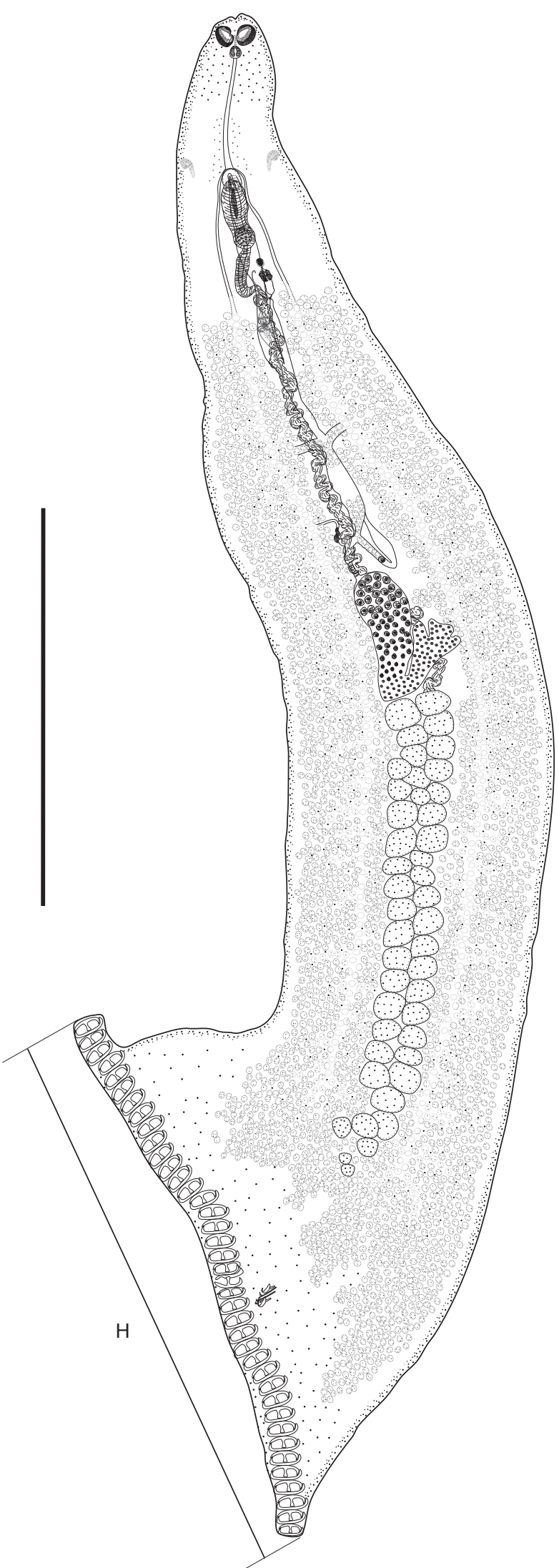

Fig. 1. Nudaciraxine imperium sp. n., composite drawing of whole worm (dorsal view). Abbreviation: $\mathrm{H}$ - haptor width. Scale bar $=1 \mathrm{~mm}$ 
A

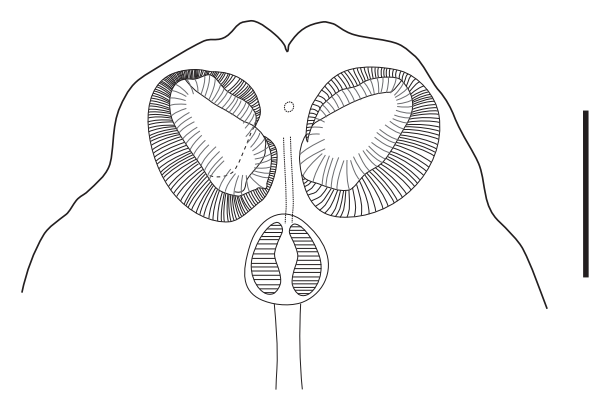

C

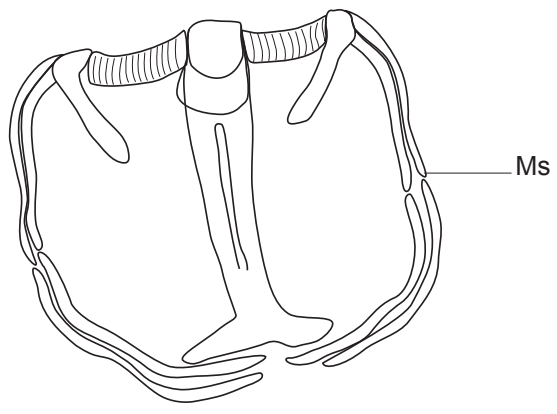

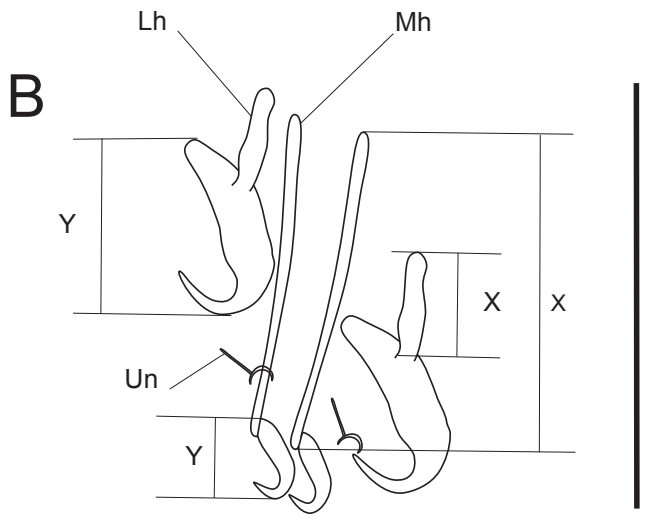

$\mathrm{D}$

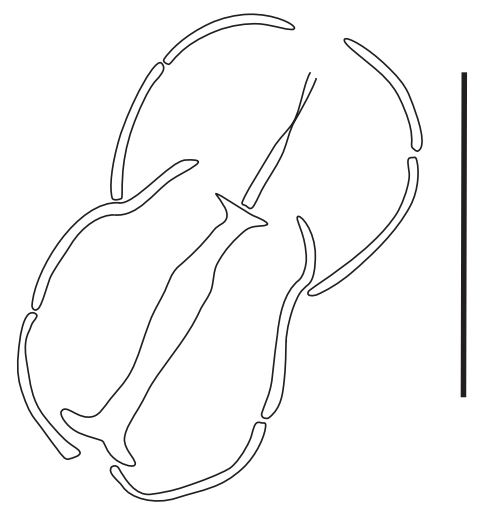

Fig. 2. Nudaciraxine imperium sp. n. A - anterior end; B - hamuli and uncinuli; C - closed clamp; D - open clamp. Abbreviations: $\mathrm{Lh}$ - lateral hamuli; $\mathrm{Mh}$ - median hamuli; $\mathrm{Ms}$ - marginal sclerite; $\mathrm{Un}$ - postero-lateral uncinuli; $\mathrm{X}$ - length of handle; $\mathrm{Y}$ - length of blade. Scale bars $=50 \mu \mathrm{m}$.

$(30-60 ; \mathrm{n}=21)$ wide at proximal globular extremity followed with anterior part of vas deferens, tubular, muscular wall; medio-dorsal, narrowed and sinuous in posterior part (Fig. 3A).

Ovary pretesticular, J-shaped, intercaecal, pre-equatorial, $420 \pm 61(300-625 ; n=15)$ long by $100 \pm 15(80-115$; $\mathrm{n}=4$ ) maximum wide. Proximal extremity divided into three lobes. Oviduct directed anteriorly, emerging from distal extremity of ovary. Dextral genito-intestinal canal branching off near distal end of oviduct. Ovovitelline duct loops posteriorly, ascending limb widens to form ootype. Mehlis' glands not observed. Vitelline follicles lateral, surrounding dendritic intestinal caeca, extending posterior to level of haptoral region. Transverse vitelloducts near halfway between vagina and ovary, joining at midline to form dorsomedian vitelloduct opening posteriorly at distal end of oviduct (Fig. 3B). Vagina $40 \pm 3$ (30-55; $\mathrm{n}=14$ ) in maximum width; entering median vitelloduct near median plane. Vaginal pore dorso-median, located at $20 \pm 2 \%(14-31 \% ; n=22)$ of length from apical margin of the body; a tiny funnel-shaped sclerotised duct after vaginal pore. Vaginal chamber slightly folded, armed with paired sclerotised lamellae in anterior half. Uterus ventral, in midline, opening at level of genital atrium in common genital pore. Egg fusiform, $590(570-620 ; n=2)$ long, $60(60 ; n=2)$ wide with two polar filaments of unequal length and curved at tips. Abopercular filament 230 (230; $\mathrm{n}=2)$ long, opercular filament $185(180-190 ; \mathrm{n}=2)$ long (Fig. 3C).

Type host: Tylosurus acus imperialis (Rafinesque, 1810) (Beloniformes: Belonidae).

Type locality: Sidi Mansour, Tunisia $\left(34^{\circ} 46^{\prime} \mathrm{N}, 10^{\circ} 48^{\prime} \mathrm{E}\right)$. Other localities: Kerkennah $\left(34^{\circ} 45^{\prime} \mathrm{N}, 11^{\circ} 17^{\prime} \mathrm{E}\right)$ and Skhira $\left(34^{\circ} 18^{\prime} \mathrm{N}, 10^{\circ} 10^{\prime} \mathrm{E}\right)$, both Tunisia.

Site of infection: Gill filaments, between secondary lamellae.

Material deposited: Holotype, Muséum National d'Histoire Naturelle, Paris, No. HEL 54 (Th 146), paratype No. HEL 55 (Th 146 bis); paratype, Natural History Museum, London, No 2008.6.3.1; voucher specimens, Natural History Museum, London, No. 2008.6.3.2; Institute of Parasitology, Biology Centre of the Academy of Sciences, České Budějovice, Czech Republic, No. M-503.

Prevalence : 39\% (29 fish infected / 74 examined).

Mean intensity: 3.1 (90 specimens / 29 infected fish).

Mean abundance: 1.2 ( 90 specimens / 74 examined fish).

Ety mology: The name "imperium" refers to the subspecies name of the host. 


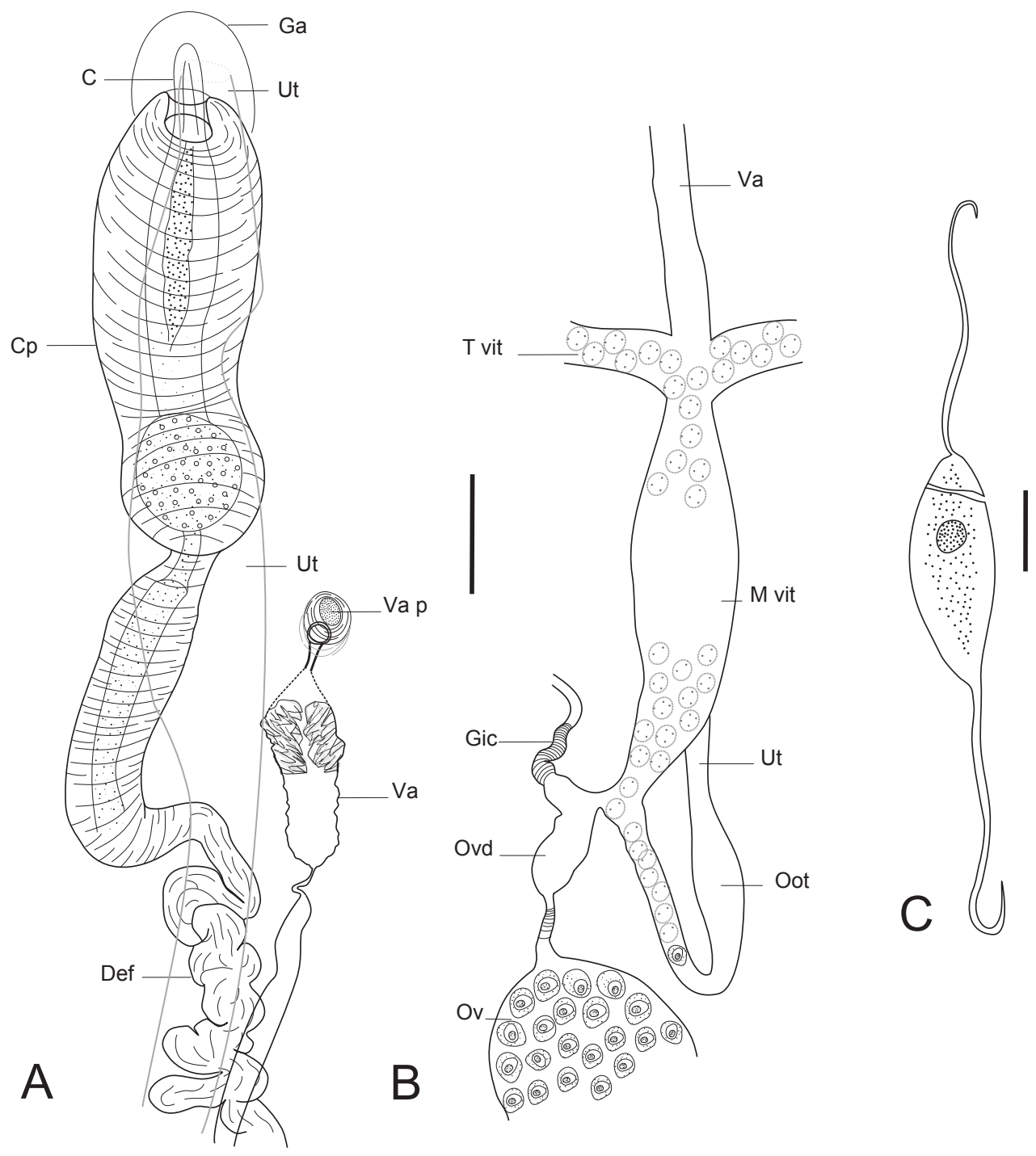

Fig. 3. Nudaciraxine imperium sp. n. A - dorsal view of anterior part of reproductive system; $\mathbf{B}$ - dorsal view of posterior part of reproductive system; vas deferens not drawn; $\mathbf{C}$ - egg. Abbreviations: $\mathrm{C}$ - cirrus; $\mathrm{Cp}$ - cirrus pouch; Def - vas deferens; $\mathrm{Ga}$ - genital atrium; Gic - genito-intestinal canal; M vit - median vitelloduct; Oot - ootype; Ov - ovary; Ovd - oviduct; T vit - transverse vitelloduct; Ut - uterus; Va - vaginal chamber; Va $\mathrm{p}$ - vaginal pore. Scale bars $=50 \mu \mathrm{m}$.

Remarks. The asymmetrical haptor with "Axine-type" clamps on only one side and the persistence of larval hamuli in adult specimens place this species within the Axinidae. The presence of numerous clamps and an unarmed genital atrium places this species within the Axinoidinae Price, 1962. The presence of an unarmed cirrus and unarmed genital atrium is an exclusive feature of the genus Nudaciraxine Price, 1962. Within this subfamily, two species have previously been described from belonid hosts: the type species $N$. gracilis (Linton, 1940) Price, 1962 found in Strongylura marina (Walbaum) from the Atlantic Ocean and N. cabosanlucensis Payne, 1990 collected from Ablennes sp. in the Eastern Pacific Ocean (California). The new species resembles $N$. gracilis in the shape and size of the body, but it differs in the higher number of testes and their arrangement (not tandemly arranged in
N. imperium). The number and width of clamps are also different. Nudaciraxine imperium has fewer and narrower clamps than $N$. gracilis ( $42-58$ vs. $42-82$ and $52-70 \mu \mathrm{m}$ vs. $75-100 \mu \mathrm{m}$ ). It differs also in the position of the vaginal aperture, which is medially located in $N$. imperium but between the median line and the body margin in $\mathrm{N}$. gracilis. The position of the vaginal aperture and the number and size of the clamps make $N$. imperium similar also to $N$. cabosanlucensis, but $N$. imperium has a J-shaped rather than U-shaped ovary. These two species differ also in the level of the oesophageal bifurcation (anterior to the genital complex in $N$. imperium vs. immediately posterior to the pharynx in $N$. cabosanlucensis) and $N$. imperium has more testes (42 vs. 20-22). Comparative measurements are listed in Table 1. These characteristics are consistent and allow us to regard Nudaciraxine imperium as a new species. 


\section{DISCUSSION}

Nudaciraxine Price, 1962 was established with the type species Nudaciraxine gracilis (Linton, 1940) Price, 1962 collected from Strongylura marina on the Atlantic coast of the United States (Price 1962). This species was first described by Linton (1940) as Axine gracilis and later reassigned to Axinoides Yamaguti, 1938 by Sproston (1946) from the same host, S. marina, from Woods Hole (North America). Since Price (1962), this species has been reported in Tylosurus acus from Veracruz (Gulf of Mexico) (Bravo-Hollis 1984).

As mentioned by Payne (1990) and after the description of $N$. imperium, the original diagnosis of the genus Nudaciraxine should be amended as follows: vaginal aperture dorsal, median to submedian, armed or not with horn-like spines. This genus now includes three species, $N$. gracilis, $N$. cabosanlucensis, and $N$. imperium.

Parona in Palombi (1949) apparently observed a monogenean "very similar" to Axine belones on Belone imperialis (old, invalid synonym of $T$. a. imperialis), but they did not describe this species. Euzet and Lopez-Roman (1973) redescribed $A$. belones from the north and south occidental Mediterranean Sea and confirmed the host of this monogenean to be Belone belone (Linnaeus). The observation of Parona might be a misidentification of N. imperium.

Nudaciraxine appears to be cosmopolitan as its species have been collected from the Atlantic and the Pacific Oceans and the Mediterranean Sea. However, this genus seems to be specific to belonid fishes. A recent molecular phylogenetic analysis has shown that the belonid genera Strongylura, Ablennes and Tylosurus, recorded as hosts of Nudaciraxine, have close phylogenetic relationships (Banford et al. 2004).

Some authors have reported axinids from Tylosurus acus but did not identify the fish subspecies. However, with reference to the geographical distribution of T. acus given by Collette (2003) and that of the axinid monogeneans, we can predict the corresponding subspecies of the host. Bravo-Hollis (1984) collected N. gracilis from Veracruz (Gulf of Mexico) and this locality corresponds to the Western Atlantic subspecies T. a. acus. Alternatively, this report could be a misidentification of the host because this monogenean was first described from Strongylura marina, which was also found in this area (Price 1962).

Pérez-Ponce de León et al. (1999) mentioned Axine resplendens and A. raphidoma from $T$. acus in the Eastern Pacific; the corresponding host subspecies might be T. a. pacificus (Steindachner). Tylosurus acus pacificus has been elevated to the rank of species as T. pacificus by Collette and Banford (2001).

On the Tunisian coast, Aspinatrium gallieni (Monogenea: Microcotylidae) was described from Strongylura
Table 1. Comparison of the morphology of Nudaciraxine imperium sp. n. with that of $N$. gracilis and $N$. cabosanlucensis. Measurements are in $\mu \mathrm{m}$, unless otherwise stated.

\begin{tabular}{|c|c|c|c|}
\hline Species & N. imperium sp. n. & N. gracilis & $\begin{array}{l}\text { N. cabosan- } \\
\text { lucensis }\end{array}$ \\
\hline Authority & Present study & Price 1962 & Payne 1990 \\
\hline Host & T. a. imperialis & S. marina & Ablennes sp. \\
\hline Body length & $3.8(2.5-5.1) \mathrm{mm}$ & $1.9-5.1 \mathrm{~mm}$ & $1.762-1.959 \mathrm{~mm}$ \\
\hline Body width & $500(300-700)$ & $200-500$ & $329-439$ \\
\hline Haptor width & $1.3(0.7-1.9) \mathrm{mm}$ & $700-1.6 \mathrm{~mm}$ & 705 \\
\hline Buccal sucker length & $53(43-70)$ & $38-47$ & - \\
\hline Buccal sucker width & $38(25-50)$ & $28-38$ & $35-42$ \\
\hline Clamps number & $52(42-58)$ & $42-82$ & $48-54$ \\
\hline Clamps length & $55(50-60)$ & - & $31-33$ \\
\hline Clamps width & $61(52-70)$ & $75-100$ & $48-57$ \\
\hline Lateral hamuli & $34(28-38)$ & $32-38$ & 30 \\
\hline Median hamuli & $47(45-50)$ & $44-47$ & 43 \\
\hline Testes number & $42(37-48)$ & $20-22$ & 32 \\
\hline Cirrus length & $170(125-190)$ & - & $64-70$ \\
\hline $\begin{array}{l}\text { Cirrus maxi- } \\
\text { mum width }\end{array}$ & $64(50-83)$ & - & $22-31$ \\
\hline Egg length & $590(570-620)$ & - & - \\
\hline Egg width & $60(60)$ & - & - \\
\hline
\end{tabular}

acus (Lacépède) on the inner side of the operculum (Euzet and Ktari 1971). In our study we found A. gallieni on T. a. imperialis in the same microhabitat (inner side of the operculum). Contrary to the majority of microcotylid species, which are attached by their clamps on the gill filaments, A. gallieni is fixed on the operculum epithelium. Open clamps work like a sucker.

Strongylura acus, the host erroneously reported by Euzet and Ktari (1971), has not been recorded in the Mediterranean Sea so far. Three species of belonid fishes are present in this area: Belone belone gracilis Lowe, Belone svetovidovi Collette et Parin, and T. a. imperialis (see Bauchot 1987, Collette 2003). According to Collette and Parin (2005), the genus Tylosurus has been widely confused with Strongylura for more than 100 years; S. acus is placed now as an invalid synonym (misidentification) of T. a. imperialis and the host of A. gallieni must be corrected as T. a. imperialis.

Four geographical subspecies of T. acus have been recorded (Collette 2003); for three of them the axinid monogeneans seem to have oixenic specificity. Nudaciraxine imperium is described from the Mediterranean subspecies T. a. imperialis. Neoaxine constricta was reported from the Indo-Western Pacific subspecies T. a. melanotus (Zhang et al. 2003) and N. gracilis was found on the Atlantic subspecies T. a. acus (Bravo-Hollis 1984). The forth subspecies, T. a. rafale, seems not have been examined for monogenea.

Acknowledgements. We thank Professor Louis Euzet for his valuable support and we are grateful to Dr. Francisco Montero for useful comments and linguistic revision. 
Banford H.M., Bermingham E., Collette B.B. 2004: Molecular phylogenetics and biogeography of transisthmian and amphi-atlantic needlefishes (Belonidae: Strongylura and Tylosurus): perspectives on New World marine speciation. Mol. Phylogenet. Evol. 31: 833-851.

Bauchot M.L. 1987: Méditerranée et mer Noire. Zone de pêche 37. In: W. Fischer, M.L. Bauchot and M. Scheinder (Eds.), Poissons osseux, Fiches FAO d'Identification des Espèces pour les Besoins de la Pêche. Vertébrés, Vol. 2. FAO, Rome, pp. 976980.

Bravo-Hollis M. 1984: Monogenea (Van Beneden, 1858) Carus, 1863 de peces del litoral Mexicano del Golfo de Mexico y del Mar Caribe X. Nuevas localidades de colecta de seis especies conocidas. An. Inst. Biol. Univ. Nac. Auton. Mex., Ser. Zool., 55: 61-71.

Collette B.B. 2003: Family Belonidae Bonaparte, 1832: needlefish. California Academy of Sciences Annotated Checklists of Fish 16: 1-22.

Collette B.B., Banford H.M. 2001: Status of the Eastern agujon needlefish Tylosurus pacificus (Steindachner, 1876) (Beloniformes: Belonidae). Rev. Biol. Trop. 49: 51-57.

Collette B.B., Parin N.V. 2005: Sphyraena acus, Lacépède, 1803 (currently Tylosurus acus) (Teleostei, Belonidae): proposed reinstatement. Bull. Zool. Nomencl. 62: 232-236.

Euzet L., Ktari M.H. 1971: Aspinatrium gallieni n. sp. (Monogenea, Polyopisthocotylea) parasite de Strongylura acus

Received 30 September 2009
(Lacépède, 1803) en Méditerranée. Bull. Soc. Zool. Fr. 96: 509-517.

Euzet L., Lopez-Roman R. 1973: Nuevos datos sobre la morfologia y la anatomia de Axine belones Abildgaard, 1794 (Monogenea). Rev. Iber. Parasitol. 33: 557-571.

Linton E. 1940: Trematodes from fishes mainly from the Woods Hole region, Massachusetts. Proc. U.S. Natl. Mus. 88: 1-172.

Palombi A. 1949: I Trematodi d'Italia Parte I. Trematodi monogenetici. Arch. Zool. Ital. 34: 203-408.

Payne R.R. 1990: Four new Monogenea (Axinidae and Heteraxinidae) from Eastern Pacific Ocean fishes. J. Helminthol. Soc. Wash. 57: 93-103.

Pérez-Ponce De León G., García P.L., Mendoza G.B., León R.V., Pulido F.G., Aranda C.C., García V.F. 1999: Listados faunísticos de México IX. Biodiversidad de helmintos parásitos de peces marinos y estuarinos de la Bahía de Chamela, Jalisco. Univ. Nac. Mex. Inst. Biol. 1-51.

Price E.W. 1962: North American monogenetic trematodes. X. The family Axinidae. Proc. Helminthol. Soc. Wash. 29: 1-18.

Sproston N. 1946: A synopsis of the monogenetic trematodes. Trans. Zool. Soc. Lond. 25: 185-600.

Tavares L.E.R., Bicudo A.J.A., Luque J.L. 2004: Metazoan parasites of needlefish Tylosurus acus (Lacépède, 1803) (Osteichthyes: Belonidae) from the coastal zone of the state of Rio de Janeiro, Brazil. Rev. Bras. Parasitol. Vet. 13 (1): 36-40.

Zhang J.Y., Yang T.B., Liu L., Ding X.J. 2003: A list of monogeneans from Chinese marine fishes. Syst. Parasitol. 54: 111-130.

Accepted 17 December 2009 